This item was submitted to Loughborough's Research Repository by the author.

Items in Figshare are protected by copyright, with all rights reserved, unless otherwise indicated.

\title{
The effect of economic restrictions on transport practices in Cuba
}

PLEASE CITE THE PUBLISHED VERSION

PUBLISHER

(C) Elsevier

LICENCE

CC BY-NC-ND 4.0

REPOSITORY RECORD

Enoch, Marcus P., James P. Warren, Humberto Valdes Rios, and Enrique Henriquez Menoyo. 2019. "The Effect of Economic Restrictions on Transport Practices in Cuba”. figshare. https://hdl.handle.net/2134/3345. 
This item was submitted to Loughborough's Institutional Repository by the author and is made available under the following Creative Commons Licence conditions.

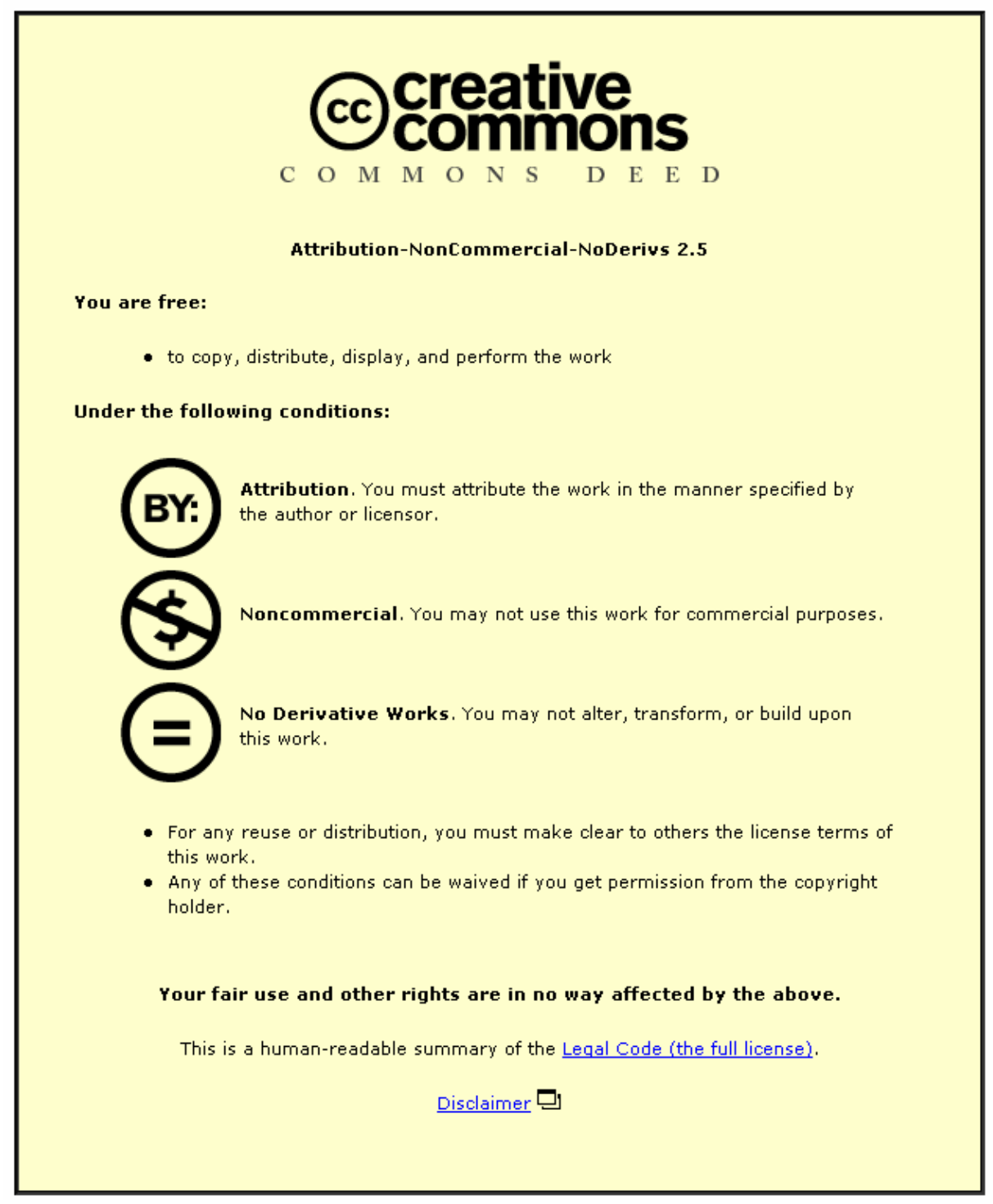

For the full text of this licence, please go to: http://creativecommons.org/licenses/by-nc-nd/2.5/ 


\title{
The effect of economic restrictions on transport practices in
}

\section{Cuba}

\author{
Dr Marcus Enoch ${ }^{\mathrm{A}}$ and Dr James P. Warren ${ }^{\mathrm{B}}$, Energy and Environment Research Unit, The \\ Open University, MILTON KEYNES MK7 6AA, UK; email: J.P.Warren@open.ac.uk.
}

Dr Humberto Valdés Ríos and Dr Enrique Henríquez Menoyo, Centre for Transport Research and Development (CETRA), Carretera del Asilo s/n, Finca Tiscornia, Casablanca, LA HABANA, Cuba.Email: humberto@iitransp.transnet.cu

\begin{abstract}
Like many developing nations, Cuba has undergone - and continues to undergo - a revolution in the way its society lives, works and accesses mobility. However, unlike other developing nations, Cuba is unique in that it has faced enormous pressures for the past forty years due to an economic blockade by its erstwhile dominant trading partner, the United States. Furthermore, this economic pressure was exacerbated in the early 1990s with the political and economic collapse of the Former Soviet Union, and the Eastern European Socialist countries which had replaced the United States as Cuba's principal trading partners. These events have led to a transformation in how goods and people are moved, not least because of a huge reduction in the amount of hard currency available to pay for fuel, vehicles and spare parts. This resulted in a number of innovative behavioural and technological outcomes.

Cuba thus provides an enhanced example of how physical, economic and social factors influence the development of transport systems. This unusually severe situation contains lessons for other countries seeking to develop more sustainable transport systems. In particular, the case graphically illustrates the link between economic and transport growth. The paper will outline the development of transport practices in Cuba thus far, look at the options available for the future and draw conclusions on what other countries can learn from the Cuban experience.
\end{abstract}

\section{Background}

The Republic of Cuba consists of two main islands - Cuba and the Isla de la Juventud, and 4,195 islets and keys, with a total area of $110860 \mathrm{~km}^{2}$. The main island is the largest in the Caribbean, measuring $1250 \mathrm{~km}$ from west to east and between $31 \mathrm{~km}$ and $191 \mathrm{~km}$ north to south. In 2001 it had a population of $11.2 \mathrm{~m}$, of whom $2.2 \mathrm{~m}$ lived in the capital Havana. Thirteen other cities have populations of more than 100,000. In 2001, Cuba's largest earners were tourism (US $\$ 1.84 \mathrm{bn}$ ), sugar (US $\$ 551 \mathrm{~m}$ ), and mining industry (US $\$ 465 \mathrm{~m}$ ), while tobacco products account for nearly another US\$263m in exports.

Cuba was 'discovered' by Christopher Columbus in 1492 but was only settled in 1511. It remained a colony of Spain until 1898, when it was ceded to the United States. The country was granted independence in 1902, but remained very closely linked politically and economically to the United States. Indeed, until 1934 the USA reserved the right to intervene in Cuba's internal affairs, while by 1958 it still accounted for around 70\% of Cuban trade (Europa, 2001; Stanley, 2000). But, following the socialist revolution in January 1959 this situation changed, as the Cuban Government began a series of land reform measures and expropriated all US business interests, in response to

\footnotetext{
A Current address: Department. of Civil and Building Engineering, Loughborough University, Loughborough, Leicestershire LE11 3TU, UK. Tel: +44 (0)1509 223408 (Direct), Tel: +44 (0)1509 222884 (Department), Fax: +44(0)1509 223981, Email: m.p.enoch@lboro.ac.uk
}

${ }^{B}$ Author for all correspondence: Dr James P Warren, Faculty of Technology

The Open University in the East of England, Cintra House, 12 Hills Road, Cambridge CB2 1PF

Tel 01223364721 extn. 66195, Fax 01223 355207, Email: j.p.warren@open.ac.uk 
what it saw as aggressive measures by the US Government. Such policies led to a marked deterioration in relations between the Cuban and United States Governments, and in February 1961 President Kennedy declared an economic, blockade of Cuba ${ }^{1}$. This action had a marked impact on the economy, and forced the Cuban Government to adopt a system of rationing. It also led to Cuba increasingly trading with Eastern European socialist countries and the Soviet Union (the COMECON group). Like most Latin American countries, Cuba's economy showed steady growth between 1940 and 1980. However, during the 1980s while the total Latin American Gross Domestic Product (GDP) actually fell by an average of $1.7 \%$ per annum, Cuba's Gross Social Product (roughly equivalent to GDP but also including state provided services) increased annually at an average rate of $6.7 \%$ (Segre et al, 1997).

This impressive economic performance was partially due to Cuba receiving preferential treatment from the USSR. It also meant that by 1989 around $85 \%$ of Cuban foreign trade was with the USSR and Eastern Europe (Diaz-Briquets and Perez-Lopez, 1995). This changed dramatically with the political and economic collapse of the Soviet Union in December 1991 and the other socialist economies between 1989-1993 (as well as the dissolution of COMECON in 1991), the trade agreements were re-written and Cuba was faced with paying the market prices for imports with hard currency.

The consequent economic crisis led the Government to declare a Special Period in Time of Peace (or State of Emergency) from September 1990. This involved measures including rationing food and clothing; increasing hard currency revenues through foreign investment; restructuring the Cuban economy to become more market-based; and lessening oil consumption through rationing public utilities, scheduled blackouts, reducing industrial production and cutting the use of motorised transport. It also led, in July 1993, to the official adoption of the US dollar as a second parallel currency to the Cuban Peso the liberalisation of some working regulations to allow small businesses to be established and to a strategy of developing tourism to raise hard currency. Despite these measures, per capita GDP fell by $4 \%$ in 1990, and further in the following years. The GDP trend is shown in Figure 1 (ONE, 1973-2002). By 1996 in became clear (as shown in the steady increases of GDP) that the reforms established in 1993 and earlier were working.

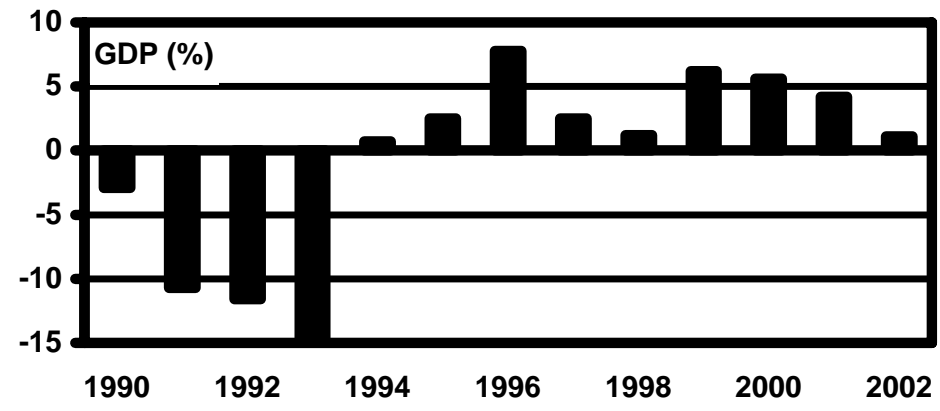

FIGURE 1: The trend in GDP (percentage change based on previous annum).

\section{Transport policy and organisation}

The Central Communist Party Congress meets every five years to set out a strategic policy framework. At the last Congress in October 1997, the main transport measures were to:

- Upgrade the main ports used for international trade;

- Improve urban, suburban, rural and inter city transport (buses and railways);

- Improve the road network and infrastructure associated with it;

${ }^{1}$ This economic blockade was further extended by the so-called Toricelli Law in 1992, and the Helms-Burton Law in 1996, which sought to 'dissuade' companies and citizens from other countries from trading with Cuba. 
- $\quad$ Link more closely the development of freight transport and with that of the economy;

- $\quad$ Continue and sustain the use of bicycles, wherever possible.

In addition, fuel deliveries to both state and private sectors were to be reduced by up to $80 \%$, tractor use was partially substituted with animal power (oxen and/or mules), and employment policy was altered to encourage people to work closer to their homes. Other measures undertaken included energy-rationing, under a scheduled blackout programme, and the part-time closure of some nickel processing and oil refining plants due to a lack of imported oil. These had significant impacts on the transport sector within Cuba, the most notable being the supply of gasoline and diesel for use for peso taxis (i.e. taxis paid for in the Cuban Peso currency). The number of dollar taxis, on the other hand, has risen in proportion to tourism, and has helped spur the growth of new vehicles on the road network in this mixed enterprise economy.

The transfer of transport policy into practice is effected by a number of Government departments at both the national and provincial levels. This section explains how this is organised for the public transport, road, automobile and rail sectors, and briefly looks at how planning is conducted.

\section{Public transport}

Nationally, public transport in Cuba is directed by the Ministerio del Transporte (MITRANS), although implementation of policy and the operation of public transport in each of the 14 provinces and the Special Municipality Isla de la Juventud, is actually carried out by 'Provincial Transport Directorates', which are subordinate to the Popular Power Assemblies. For example, in the Province of the City of Havana, Provincial Transport Authority functions are carried out by 11 divisions. These are:

- Omnibus Metropolitanos (OM) - metropolitan buses

- MetroBus - "camellos", converted from truck based (military) tank transporters

- $\quad$ Autos (also known as Panatrans) - taxi, rental car, and drivers training companies

- Transporte Escolar - educational transport

- Ferrocarriles Metropolitanos - (suburban railway)

- Produccion y Talleres - production workshops

- Talleres Automotores - maintenance workshops

- $\quad$ Servicentros - fuel service stations

- $\quad$ Proveedora General del Transporte - vehicle parts

- Construccion y Mantenimiento - building and maintenance (property)

- Consultoria economica - statistics, planning, finances

Public transport must be self-financing. Until 1994, general government funds from MITRANS (of around \$US4m per annum) were used to fund the Provincial Transport Directorate in the City of Havana budget. Public transport in Havana has always been able to cover operating expenses, that are paid in Cuban Pesos through the fares. But there has been a constant problem with financing fuel, new vehicles and spare parts and other supplies which require hard currency i.e. US dollars - which led to a reduction in service provision. To address this, enterprises that generate hard currency (e.g. the tourist taxis, tourist rental cars, and tourist cocotaxi elements of Panatrans and the Transmetro services that hire out buses and trucks to dollar-owning companies) cross subsidise the other services, in particular OM and MetroBus.

In addition, a service planning team from the Regional Transit Authority of Paris (RATP) has been working to redefine the public transport network in the capital. The main aim of this project has been to rationalise the number of existing routes to match the actual passenger demand. The first of these new principal routes has already been put into place. 


\section{Roads}

Responsibility for the building of roads nationally resides with the Ministry of Construction. Maintenance falls to the regional MITRANS offices. Roads that carry public transport vehicles are given priority for repair over smaller roads. There are nearly $61,000 \mathrm{~km}$ of roads in Cuba, of which $28 \%$ are paved rural roads, $27 \%$ paved urban roads and $45 \%$ are unpaved rural roads. The most important road is the Central Highway which runs for $1,200 \mathrm{~km}$ from Pinar del Río to Santiago.

The state of the Cuban road system, like other parts of the national transport infrastructure, is dilapidated due to a continual lack of maintenance. Road surfaces have continued to deteriorate during the 1990's due to lack of resurfacing with only major repairs to certain areas being undertaken. The government has had to take a stance of limiting road resurfacing to every 15 years, rather than the intended ten years. Due to this lengthened period, the refurbishment costs rapidly increase as roads deteriorate far more quickly the longer they are neglected. Currently it is suggested that only $46 \%$ of all the paved roads are in a 'good' condition due to the lack of road maintenance.

\section{Cars}

In Cuba, cars tend to be one of three types. There are privately-owned (generally US built cars bought before the 1959 revolution, plus some vehicles from Eastern Europe, the USSR and other countries), which were sold to some officials, university graduates, national vanguard workers and other public and private sector workers at a discount. Finally, there are Government/tourist cars (that are usually Asian/Western European-built cars from 1990 onwards).

Many of these vehicles are also registered as taxis. As of 2002, the Police Department of Ministerio del Interior (MINIT) was conducting a major car census by introducing new registration plates. Plates for all vehicles in use will be updated allowing the first verified count of all vehicles within the country. The main problems facing vehicle owners are the lack of basic supplies including spare parts, fluids and tyres which can result in vehicles which might be considered not road-worthy. Furthermore, with a severe strain on parts, high levels of recycling parts or the use of makeshift piecework is a common solution. Currently, it is estimated that there are some 173,000 cars, 29,000 buses, nearly 160,000 lorries and vans, 180,000 motorcycles and 11,400 tractors, equating to 32 vehicles per 1000 population, although it is difficult to verify this number ${ }^{2}$. This is because it is known that many cars are registered but no longer exist (having been cannibalised for spare parts for example), while other cars are being stored in barns or garages but are no longer registered nor being used. A similar trend for light duty trucks can been observed, especially in Havana, where many open-body trucks have been converted into makeshift collective buses and taxi vehicles. In the case of all vehicles, but especially collective taxis, there is a drive for highoccupancy to ensure maximum efficiency (as will be shown later). Interestingly, motorisation as a function of income in Cuba broadly matches that found for many low income developing countries such as the Philippines and the Ivory Coast (Gakenheimer, 1999; IRF, 2000). This is despite the unique difficulties Cubans have in buying vehicles, vehicle parts and fuel. For a direct comparison, Figure 2 shows the current rate of motorisation (vehicles/1000 inhabitants) in various countries (IRF, 2000) including some of Cuba's nearest island states, as well as some others which are frequently linked for comparison purposes. Although precise values for Cuba (shown as an $X$ in Figure 2) are yet to be determined, estimates show that the numbers of vehicles in Cuba is similar to their geographic neighbours, as well as others in similar conditions. In general, one can group the countries shonw into 4 or 5 distinct clusters based on the GDP and motorisation level. Cuba is comparable with Haiti, Nicaragua, Bolivia, Honduras and Ecuador. The second cluster (>\$30005000 GDP) contains Guatemala, Paraguay, Jamaica, Peru and El Salvador. Columbia and the Dominican Republic are just above the $\$ 5000$ GDP threshold along with Brazil, Panama and Venezuela. Countries from \$8000-10000 are: Costa Rica, Mexico, Chile and Uruguay. The highest motorisation rates shown here (and GDPs) are observed in Puerto Rico, Argentina and Barbados. The figure is meant to be indicative of where Cuba lies in the GDP and motorisation 'map' and other work has shown that in many cases the correlation is much stronger when the highest percentiles of the GDP are linked to motorisation (Gakenheimer, 1999).

${ }^{2}$ For comparison, the number of vehicles per 1000 people in 1997 was 110 in Chile, 45 in Ecuador, and 17 in Guatemala. In the USA the number was 767 (IRF, 2000). 


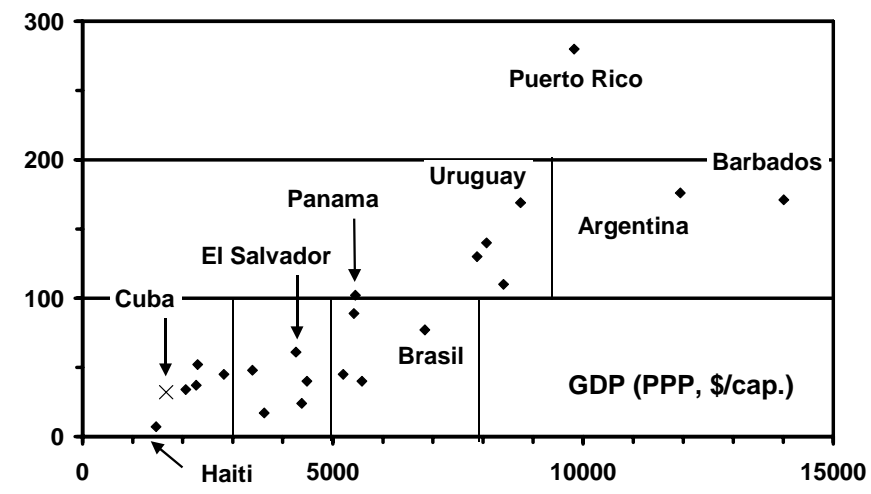

FIGURE 2: The rate of motorisation (vehicles/1000 persons) as a function of GDP, for various developing countries.

Rail

The railways in Cuba are nationalised and run by the UFC (Union de Ferrocarriles de Cuba Union for Railways of Cuba) for passenger and freight traffic, and for sugar-related haulage by MINAZ (Ministerio del Azucar - the Ministry for Sugar). In 2000, there was $11,151 \mathrm{~km}$ of track, of which $38 \%$ was dedicated for public use; the remainder is used primarily for freight (mostly as sugar cane). With only slightly more than 200 locomotives, and approximately 700 passenger coaches, passenger rail patronage is severely constrained by lack of diesel powered locomotives. Currently annual passenger volume is some 12 million per annum, but demand is estimated at twoand-a-half to three times this value, with the busiest route being between Havana and Santiago de Cuba, some $836 \mathrm{~km}$ apart by rail. The rolling stock has an average age of about 30 years leading to reliability problems, and both passenger and freight rail traffic volumes are decreasing as a result.

\section{Planning}

Land use planning is tightly controlled, with $75 \%$ of the land owned by the Government and the remainder owned by co-operatives and small-scale farmers. All cities with populations over 20,000 have a land use plan which illustrates exactly what type of development should be built where.

\section{Overall Characteristics}

Clearly Cuba is a developing country, but on the other hand its economic circumstances have been distorted by external economic effects for so long that it also exhibits a number of unique characteristics. Gakenheimer (1999) outlined a series of distinguishing features typically exhibited by developing countries, noted in Table 1. 


\begin{tabular}{ll}
\hline Characteristics \\
\hline 1. \\
2. Trapid pace of motorisation - \\
facilities, particularly road space \\
3. High share of trips by public transport \\
4. Intense desire for auto ownership and use
\end{tabular}

5. Urban structure incompatible with motorisation

6. Stronger land use/transportation relationship due to faster rates of development

7. Greater differences in vehicle performance

8. Inadequate street and highway maintenance

9. Fewer legal constraints on the use of new technologies

10. Weak driver discipline

11. Very limited agreement on planning approaches

12. Capital is scarce and operating subsidies difficult to sustain

13. Local transportation development is more centralised
Comments on the Cuba situation

Certainly not true due to the economic

blockade and Government policy.

True, although it is public transport rather than road capacity that is the critical variable.

True. Green modes too are well used.

There is a desire for auto ownership, but most people see this as a distant dream rather than a possible goal.

Current land use patterns are incompatible with motorisation, while development is taking place according to a strict land use plan that aims to promote the use of green modes and public transport, while limiting car use.

Development is probably slower than in other Developing Countries due to the lack of available hard currency resources.

Wide variety of vehicle types. Many developed as a direct response to the Blockade.

Clearly the case due to the lack of hard currency resources.

True. People encouraged to get around by any means they can.

Possibly true, although traffic laws are rigidly enforced and there are many police.

Planning approaches would appear to be consistent.

A lack of hard currency is the major problem.

True, although provinces do have some say in how transport is organised.

Table 1: Transport characteristics in developing countries: The case of Cuba (Adapted from Gakenheimer, 1999)

From this, Cuba exhibits 'typical' developing country transport features in the majority of categories. Crucially however, the economic crisis has dramatically slowed the pace of motorisation while a strong political lead (again combined with the economic situation) has ensured that development has been tightly controlled.

\section{A transport crisis examined}

The impact of the post-Soviet State of Emergency on travel patterns in Cuba is difficult to measure due to the large number of different responses, many of them informal, made by Government and by individuals. However, if figures on the number of vehicles and the amount of oil used in the transport sector are examined - perhaps the most obvious proxies for mobility - the situation was calamitous. Cuban imports as a whole fell by 75\%, from 8.1bn Cuban Pesos in 1989 to 2.0bn Cuban Pesos in 1993, while over the same period in the transport sector, fuel (i.e. oil) imports were cut by $76 \%$, and imports of transport equipment fell by $86 \%$ (Farah, 1992; DiazBriquets and Perez-Lopez, 1995). One example of how this affected transport provision is illustrated by the bus sector. In Havana, by May 1993 the number of operational buses was only 500 compared to 2,200 before the collapse of the socialist block, while outside the capital the number of bus routes operated at the end of 1992 had been cut by more than $80 \%$ compared with three years earlier.

More generally, the effects are illustrated in Figure 3, which summarises the average annual kilometres travelled on public transport (rail, bus, state-owned vehicles, air and sea) per person. Overall this has declined significantly, having peaked at nearly $3000 \mathrm{~km} / \mathrm{yr}$ in 1986 , and fell rapidly to a low of $744 \mathrm{~km}$ by 1995 . Although by 2000 it had stabilised around $850 \mathrm{~km}$, this remains at early 1960 's levels. Note that this analysis is only based on motorised values and as such does not consider the importance of pedestrian, bicycle and private car journeys. This mobility index is broadly comparable with the poorer Latin American countries. El Salvador $(718 \mathrm{~km})$ and Ecuador 
(1245km), for example, exhibit similar motorised mobility levels to Cuba. These figures translate to a value in millions of passenger trips of 3.6 billion per annum at the peak in 1986 (or around 10m a trips a day for a population of $11.2 \mathrm{~m}$ ) dropping to $0.5 \mathrm{~m}$ trips in 1995 , but increasing again to $0.8 \mathrm{~m}$ five years later.

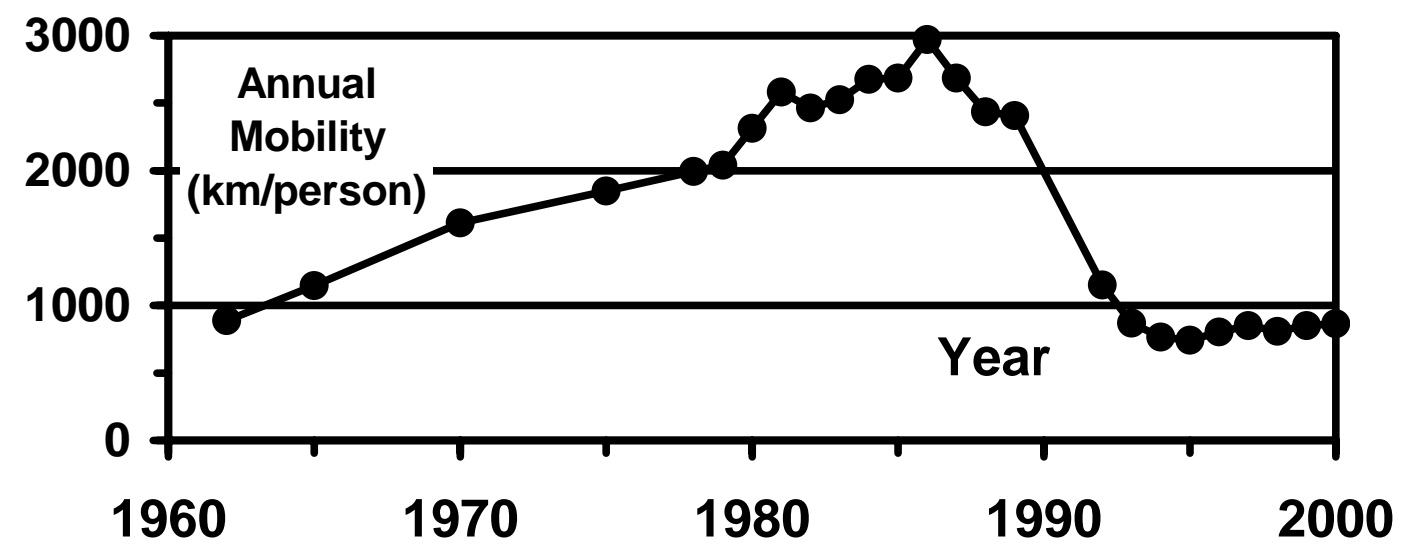

FIGURE 3: The trend in kilometres travelled per person per year for Cuban citizens for the period 1962 to present.

For completeness, it should be noted that along with mobility, factors such as traffic noise, emissions, energy use, road deaths etc. should be considered. The low level of travel (even in 1990 ) is reflected in the very low carbon dioxide emissions from transport per capita, with Cubans generating a mere 0.5 tonnes per annum compared with 20 tonnes per person in the USA, 11 in Germany, nine in Japan, five in Portugal, and two in China (Díaz, 1998). For road accidents, in Cuba in 1997 IRF (2000) reports that there were 8857 injuries and 1309 deaths on the road - a rate of 11.8 per 100,000 population. It is notable that low mobility has not cut road accident rates; Cuba's are fairly typical for South America and compares with a rate of five deaths per 100,000 in Mexico (1994), 17 in Brazil (1995), and 32 in South Africa (1992). The corresponding figures in the UK was six (1997), and in the USA 16 (1995) (Vasconcellos, 2001; IRF, 2000).

\section{Transport Responses to the Economic Emergency}

Returning to the issue of mobility, while the total number of trips fell, many were substituted by a combination of more walking and cycling, increased vehicle occupancy and the development of new modes. This phenomenon is illustrated using data gathered in Havana in 1981 and 1998 (see Table 2).

\begin{tabular}{lll}
\hline Mode & \% in 1981 & \% in 1998 \\
\hline Pedestrian $^{\star * *}$ & 6 & 43.0 \\
Bicycle $^{*}$ & $\leq 1$ & 13.5 \\
Enterprise bus $^{*}$ & - & 10.8 \\
Other $_{\text {Public bus }}$ & 3.5 & 10.8 \\
Camello & 84.5 & 9.5 \\
Car & - & 6.7 \\
\hline
\end{tabular}

Table 2: Percentage transport mode distribution in Havana in 1981 and 1998 (Alepuz and Valdés Ríos, 2002)

\footnotetext{
${ }^{* *}$ Bicycle was not measured directly and is estimated to be approximately $\leq 1 \%$.

*Includes ferries, suburban railway, cicliobus, tricycles, motorcycles and other modes.
} 
Particularly noticeable is how the modal share of motorised transport fell from $93 \%$ to about $43 \%$ over the period, making Havana one of the most non motorised cities in the world ( $57 \%$ modal share) just under Beijing, China (62\%), Jaipur, India (66\%), and Bobo Dioulasso, Burkina Faso (87\%) (Vasconcellos, 2001). In addition, the share of cycling increased from $0.5 \%$ to $13 \%$, despite the problems of increased accident rates, unreasonably long cycling distances and the need for bicycle infrastructure and support facilities.

\section{Demand side responses}

The economic downturn effectively cut demand for freight transport and the lack of transport supply has effectively forced many people to either make fewer trips, or else made them 'trip chain' more efficiently. Overall, transport demand was suppressed.

Land use planning too has been used to control trip lengths, which is unusual in a developing country. Typically, cities deploy a strong green belt policy to prevent urban sprawl, and new developments are concentrated along public transport corridors. In addition, mixed-use developments are encouraged so that where new housing is constructed for example, enough new schools and shops are also provided to maximise walking opportunities.

Data on how much travel was reduced through people moving house or job or by changing working patterns are difficult to find. However, it was realised that there were many not-toospecialised workers who had jobs far from their homes. A system was therefore put in place to allow people to exchange their job for one closer to their home, which resulted in over 10,000 people exchanging their jobs to reduce the time and resources spent on commuting (Huot, 1997). In the case of a person having to change their job location (in order to be closer to their residence) the government guaranteed an equal salary for the new job position, even if the work position should have been paid a lower rate. This state subsidy was felt by Government to cost less than the savings made on energy for transport and time under this scheme. In addition to this subsidy, the State of Emergency regulations allowed businesses and work centres to change their working patterns. In some cases where the business previously had been open six days a week, a more flexible pattern emerged, where only alternate Saturdays were staffed. Others reduced to a five day week with the same level of total hours worked. These changes had subtle effects on the demands for transport as the peak times were either condensed or smoothed out. The policy did not apply to rural areas, and no farm workers were transferred to work in urban areas. However, while moving jobs (and creating flexible working times) was made possible in Cuba, moving house is more complicated, involving a lot of bureaucracy and/or money. This has proven to be a key barrier, and as a result, the flexible working practices are not thought to have been a significant influence on the reduction in travel.

\section{Supply systems effects}

On the supply side, fuel and spare parts became increasingly scarce meaning that formal public transport services in particular became less frequent and less reliable. Policies were therefore adopted to increase the efficiency of the vehicles available. This was done in several ways. Firstly, new informal public transport modes such as truck transport and employer-operated work buses were developed. Secondly, the occupancy of existing vehicles was increased through measures such as organised and informal hitchhiking and the encouragement of 'collectivo' taxi sharing schemes. Thirdly, technological developments in alternative fuel types were made. Fourthly, regulatory and fiscal instruments designed to limit the demand for the small number of private cars were adopted. Finally, walking and cycling were encouraged, as was the adoption of animal-powered traction.

\section{New modes}

With the reduction in usable buses available to serve passengers, public transport agencies were forced to consider developing new modes. In Havana, flatbed truck trailers pulled by ex-army lorry cabs were given sides, seats, doors, windows, and roofs so they could carry 220 passengers at one time. In 2002, there were $\sim 180$ 'camellos' (called camels because of the 'hump' in the design) operating on seven core 'colour-coded' routes. The network operates as a surface metro system, with route distances of around $20-23 \mathrm{~km}$ and an average distance between stops of $1.5 \mathrm{~km}$, compared with around $400 \mathrm{~m}$ for bus stops. Service frequencies range from four-minute to ten- 
minute intervals. The camello network currently carries around 250,000 passengers each day in Havana, compared with 374,000 by other public buses (Valdés Ríos, 2002). Outside of the capital too, truck transport is important although the only concession to passengers may often be a plank of wood to sit on and sometimes not even that.

Prior to the State of Emergency, works buses had been used only where companies were not located on a bus route or where workers were required to work late evening or early morning shifts. But, the severe drop in service levels meant that by 2001 there were some 3,500 works buses carrying around 300,000 people a day. In general, these are older buses donated by or bought second hand from sympathetic public transport operators from across the world. These tend to cater only for commuter journeys and travel only $25 \mathrm{~km}-50 \mathrm{~km}$ a day, compared with $150 \mathrm{~km}$ $200 \mathrm{~km}$ driven by a public bus each day.

Coco-taxis carry up to three dollar paying passengers in a coconut shaped - hence the name - fibre glass shell that is bolted onto a motorcycle chassis, rather like Tuk-Tuks found in South East Asia.

In order to extend the use of bicycles through the tunnel linking central Havana with Habana del Este, a so-called 'cyclo-bus' service was introduced in 1991. This was originally operated using trucks with a trailer attached, but in 1992 these were replaced with buses. Currently, six vehicles operate at a time, with four spares. Each vehicle can carry up to 22 bicycles, plus cyclists and other passengers. The fare is ten Cuban Peso cents per passenger or 20 Peso cents per bicycle or moped for the $4 \mathrm{~km}$ journey. Around 4,200-4,300 passengers are carried daily, on 105 vehicle trips.

\section{Increasing vehicle occupancy}

Given the lack of available transport, hitchhiking is widespread throughout Cuba. This usually occurs on an informal basis, with people waiting at road junctions or by the side of the road thumbing for a lift. However, hitchhiking is also officially encouraged through legislation that requires certain Government vehicles to stop and give lifts when they have space available. In addition, at busy road junctions on the edge of some major towns, 'amarillos' (yellow men) are employed by provincial transport departments to facilitate hitchhiking. There are usually about three amarillos per junction, each dealing with around 1,000 passengers a day, and the system operates seven days a week from roughly $6 \mathrm{am}$ to $6 \mathrm{pm}$. As well as matching passengers to vehicles, the amarillos take notes on the buses that pass. They do not deal with fares or tariffs, as these are strictly a matter between the rider and the driver. Car sharing is seen as particularly useful for people with packages, who would find it very difficult to board a bus or a camello. Overall, Cuban officials estimate that there were $31.5 \mathrm{~m}$ hitchhiker trips made in 2000.

The use of taxis is also maximised through the use of 'collectivo' shared private taxis. These perform as supplementary buses, by collecting passengers at established pick up points, and then dropping people off and picking people up along fixed routes.

\section{Technological developments}

One solution to the vehicle spare parts crisis was to take two Lada car bodies and convert them through a cutting and welding process into a single longer-bodied 'stretched wheel base' Lada 'Limousine' which could accommodate more people. This was a response to the lack of replacement engines for the vehicles - the motor represents the critical piece needed in Cuba.

There is still widespread use of steam-powered locomotives (approximately 290) for the sugar cane haulage industry and for steam train tourism. Although steam engines do have an inherently lower efficiency when compared to diesel locomotives, they do give acceptable levels of speed and haulage. Various government industries in a cross-ministry effort have undertaken a research programme to re-evaluate the use of steam for both passenger and freight transport using a lighter type of locomotive. The engine boiler can be run on various fuel types including coal, wood, fuel oil and biomass. The use of bagasse (the final crushed cane fibre which remains after milling) is currently an important part of the animal feedstock for cattle, but this could easily be utilised as a biofuel. Running locomotives on sugar cane derived by-products is a distinct possibility which provides environmental benefits, is sustainable, and is locally sourced. This project is well under way with a single test locomotive already constructed and being tested. 
Regulatory and fiscal instruments

Petrol rationing was until 1992-93 the favoured instrument for allocating fuel to vehicle users. Typically, vehicle owners (or their employers) were given coupons entitling them up to 20 litres a month. With the adoption of the US Dollar as a legal currency, rationing was dropped and owners must buy their fuel instead at the market rate. Officially there is no tax on petrol, which is sold in US dollars. But, the state-owned Cuban oil company Union del Petroleo (CUPET) charges drivers around US $\$ 0.90$ a litre, while buying crude oil at around US\$0.22 (although this crude oil must then be processed and distributed across the country). Currently, around $10 \%$ of the one million tonnes of petrol and diesel used each year by particular enterprises in the transport sector (e.g. for the police, hospitals, agricultural workers, public transport companies, etc) is set aside - i.e. effectively subsidised by the Government.

In terms of other fiscal mechanisms to limit car use, there are no purchase taxes on cars while the annual registration tax is nominal. In addition, there are currently two toll roads in the country, both in areas serving mainly tourist traffic. Drivers must pay a US $\$ 1$ fee at the entrance to the freeway to Varadero and on the road to Cayo Coco. These tolls began in 1996 and were specifically chosen due to their importance as major tourist centres. Money raised from the fees goes directly to the Ministry of Transport who uses it to fund road maintenance programmes.

\section{Alternatives to motorised travel}

With the reduction in bus service levels caused by the lack of spare parts and the fuel shortage, the number of walking trips in Cuba rose significantly as did trip walk length. As of 2002, the average length of walk trip is estimated at $5 \mathrm{~km}$, while more than half of walk journeys take longer than 40 minutes.

Prior to 1990, there were virtually no bicycles in Cuba, but with the State of Emergency a team of 25 planners was formed in March 1991 to design the various bicycle facilities that would be necessary for safe and efficient circulation of bicycle traffic. More than two million bicycles were bought from China and sold to Cubans for a fraction of the cost. Local factories were also established which produced some 150,000 bicycles a year during the mid-1990s. As of 1997, there were approximately two million bicycles in the country, half of which were in Havana (Huot, 1997). In addition, the bike road network (lanes, cycle routes and safety measures) was completed. Related to the increase in bicycle use, was the introduction of the cyclo-taxi - pedal-powered tricycles that can carry up to two passengers. In ten provinces in Cuba in 2000 (not including Havana, Matanzas, and Cienfuegos), they made $9.3 \mathrm{~m}$ passenger trips. While the peak usage of bicycles was in 1994, by 1998 there were still 529,000 cycle trips per day in Havana. Bikes also accounted for $14.4 \%$ of commuting trips - i.e. more than were made by urban bus, camellos or works buses. The typical cycle distance was $4.4 \mathrm{~km}$ while the average travel time was 34 minutes $^{3}$. To substitute the bicycles would require 128 buses, 57 more camellos or 300 more work buses (Valdés Ríos, 2002). However, cycle use has since declined due to a number of reasons, including a slight improvement in the bus service and a decline in the services to cyclists (repair shops, cycle parks etc.).

The use of animal traction for freight transport, passenger transport and agriculture increased significantly from 1991 onwards. This has almost exclusively been provided by the private sector. From 1998, owners of animal traction vehicles have been required to register with provincial or municipal offices of the State Traffic Unit for a Licence for Transport Operation. By 2000 , there were more than 16,000 animal powered buses, carts, carriages and wagons. Interestingly though, the number of horses, mules and donkeys in 1998 was only $55 \%$ of the number in 1977 - 464,000 compared with 849,000 - and this could be a constraint on the further development of animal traction. In 2000 , animal traction accounted for $93.2 \mathrm{~m}$ passenger trips in the 13 provinces outside of Havana. Further information is therefore required about how to more efficiently manage horses, mules and donkeys in urban and rural areas (Valdés Ríos, 2000).

${ }^{3}$ Interestingly this average journey length is less than that of pedestrians, while the average speed of $9 \mathrm{~km} / \mathrm{hr}$ is sedate to say the least. This may have something to do with the poor quality of the bicycles and road surfaces. 


\section{Where next for Cuba?}

Future transport policy in Cuba will be significantly influenced by whether the US Blockade is lifted or not. Assuming the Blockade is not lifted in the near future, policy will continue to focus on increasing the service level provided by formal public transport (i.e. buses) through building more vehicles and through efficiency gains. Ultimately, this would also involve replacing the camellos with articulated-buses or electric trolleybuses (or even light rail systems in the longer term) within Havana, although this policy would be heavily dependent upon whether sufficient hard currency could be raised.

If the Blockade were reduced or lifted, there would be a rise in economic and hence transport activity. It is difficult to estimate what this growth would be in a country free of constraints, but Cuban Government sources anticipate an immediate increase in the number of tourists from around $2 \mathrm{~m}$ a year currently to $4 \mathrm{~m}-7 \mathrm{~m}$. To deal with this potential influx, plans are already in place to allow the transport systems in place to grow significantly. In addition to the proposed replacement of the camellos with trams or high capacity buses in Havana, parking controls would be put into place in order to collect revenue along with appropriate land use policies. Meanwhile there would need to be investments in the maritime connections, including a programme to ensure that congestion around ferry ports (previously major entry points for American tourists) would not significantly increase. Cruise ships would also need to be catered for, while private car ownership would be reviewed after an initial period of unconstrained growth. One scenario would see the private vehicle owners being taxed heavily in order to discourage ownership and encourage the use of public transport systems and sustain non motorised means, e.g. bicycle usage. On top of this tourist influx, the increase in overall economic activity would certainly encourage increased mobility - much of it by motorised modes and maybe the private car in particular.

In conclusion, the development of transport policy in Cuba has been heavily influenced by the condition of the national economy, which in turn has been dominated by the US Blockade and by the collapse of the USSR and the socialist regimes of Eastern Europe. This has led to a unique situation, whereby a fairly advanced country has been forced to curtail its natural economic development. This has had an effect at the national level as well as at the individual-personal choice level.

At the national level, the planning policy mechanisms have reduced the need for travel, while the lack of transport supply has ensured that only 'necessary' trips are made. On top of this, the lack of fuel and spare parts has meant that those trips that are made are carried out either on vehicles operating at very high capacity or by using less or non-polluting modes. At an individual level, citizens are extremely aware as to the cost of transport and as such tend to conduct those journeys that are necessary, and then by the most efficient means. As a consequence, in terms of energy use at least Cuba now has a relatively environmentally benign transport system, although the localised pollution can be very bad due to the poor fuel quality and antiquated vehicle fleet.

Overall, in reacting to an unprecedented set of circumstances the Cuban Government and people have devised a whole range of sophisticated and innovative responses in order to maintain necessary mobility. The current position, is not likely to last for long, and as the Cuban economy grows the issue of suppressed demand will become increasingly problematic. While planners and policy makers in Cuba are clearly committed to keeping the car in check, the evidence from many other less developed nations suggests that even socialist countries such as China and Vietnam are now accepting their populations desires to own and use cars. Indeed car ownership in China is increasing at a rate of $15 \%$ per year, and Government surveys that show how Chinese families are prepared to spend two year's income for a car that is expected to last ten years (Gakenheimer, 1999). However, with very careful preparation it may just be possible for Cuba to avoid many of the pitfalls of mass car ownership already experienced by other countries that had been unhindered by external and political forces. Higher transport use is inevitable, but America's blockade may have nudged Cuba towards a more sustainable and less transport intensive society than would otherwise have been the case.

\section{References}

Alepuz M and Valdés Ríos H (2002) The urban transportation in time of crisis: The case of Havana, Proceedings of CODATU X, Lome, Togo, 12-15 November. 
Díaz J J A (1998) Emission of Greenhouse Gases by Cuban mobile sources in 1990, Transport Development and the Environment, Vol.18, No.3, December, pp.11-16.

Diaz-Briquets S and Perez-Lopez J F (1995) The Special Period and the Environment, Proceedings of the $5^{\text {th }}$ Annual Meeting of the Association for the Study of the Cuban Economy, Miami, Florida, 10th-12th August. Cuba in Transition, Volume 5, ASCE, Washington DC.

Europa (2001) The Europa World Year Book 2001, Volume I, Taylor and Francis, London, pp.1254-1265.

Farah D (1992) Cubans are feeling unempowered, The Washington Post, Washington DC, 21 December.

Gakenheimer R (1999) Urban mobility in the developing world, Transportation Research Part A, Vol.33, pp.671-689.

Huot, C (1997) The Cuban Bike Revolution, Feature, The Sri Lanka Daily News, 20 October, Sri Lanka. Third World Network Features, Penang, Malaysia. http://www.blythe.org/nytransfersubs/97env/The Cuban bike revolution-TWN. Accessed 27 May 2002.

International Road Federation (2000) World Road Statistcs 2000, IRF, Geneva.

Oficina Nacional de Estadísticas (1973-2001) Anuario Estadístico de Cuba (1973-2001), Oficina Nacional de Estadísticas, Havana, Cuba. Editions for 2002, 2001, 1989, 1988, 1982, 1981, 1980, 1974, 1973.

Segre R, Coyula M and Scarpaci J L (1997) Havana: Two Faces of the Antillean Metropolis, John Wiley and Sons, Chichester.

Stanley D (2000) Cuba, Lonely Planet, $2^{\text {nd }}$ Edition, London, July.

Valdés Ríos H (2000) Public transport services using animal power in Cuba, National Animal Traction Research Programme, Department for International Development, London, November. http://www.recta.org. Accessed April 2002.

Valdés Ríos H (2002) Sustainable transport in Cuba: Case studies on bicycles and 'camellos', Research Paper, Centre for Transport Research and Development, Havana, Cuba, 7 April.

Vasconcellos E A (2001) Urban transport, environment and equity: The case for developing countries, Earthscan, London.

\section{Acknowledgements}

The authors are indebted to those at the Centre for Transport Research and Development (Grupo IT/CETRA) and the Ministry of Transport (Cuba) for their assistance in supporting our data collecting as described in this paper - including Ministry of Basic Industries, Union for Railways of Cuba, Office for National Statistics, and the Province of the City of Havana Transport Authority. Thanks are also due to the Faculty of Technology at the Open University for providing financing the research, and our colleagues Dr Stephen Potter and Dr Graham Parkhurst for their comments on this article. 